\title{
An Occurrence of the Hawkweed-Leaved Saxifrage, Saxifraga hieraciifolia, in Southern British Columbia, and its Palaeobotanical Implications
}

\author{
STUART A. HARRIS \\ Department of Geography, University of Calgary, Calgary, Alberta T2N 1N4 Canada
}

Harris, Stuart A. 2003. An occurrence of the Hawkweed-Leaved Saxifrage, Saxifraga hieraciifolia, in southern British Columbia, and its palaeobotanical implications. Canadian Field-Naturalist 117(2): 304-306.

The Hawkweed-Leaved Saxifrage (Saxifraga hieraciifolia), normally found in the alpine tundra in the Arctic, has been collected at $445 \mathrm{~m}$ in parkland near Chase, British Columbia. The closest previously recorded occurrence was on the tundra of the Liard Plateau, northern British Columbia. The new occurrence indicates that this species had migrated at least as far south as northern Washington State before the Late Wisconsin glaciation. The latter eliminated the species in British Columbia, but a small population survived south of the glaciers and then, after deglaciation, it migrated north into southern British Columbia, but along the lower limit of the main Boreal Forest instead of above treeline.

Key Words: Hawkweed-Leaved Saxifrage, Saxifraga hieraciifolia, distribution, glaciation, disjunct, British Columbia.

Hultén (1968, page 580) shows the distribution of the Hawkweed-Leaved Saxifrage (Saxifraga hieraciifolia Waldst. and Kit.) to be circumpolar. More recent additions have been reported for the Northwest Territories and Yukon Territory by Porsild and Cody (1979), Cody (1996), Cody et al. (1998), and W. J. Cody (personal communication). Straley et al. (1985) indicate that it only just enters British Columbia in the northwest at Mount Mansfield and in the northeast on the Liard Plateau at latitude $59^{\circ} 45^{\prime} \mathrm{N}, 125^{\circ} 30^{\prime} \mathrm{W}$ (Figure 1). Douglas, Meidinger, and Penny (2002) and Douglas, Meidinger, and Pojar (2002) also show only these records. All authors consider it to be a species found in moist places on tundra, on alpine meadows, and on soils undergoing solifluction.

While collecting plants at $50^{\circ} 48^{\prime} 07.2^{\prime \prime} \mathrm{N}, 119^{\circ} 44^{\prime}$ 20.6" W, on the eastern margin of the Okanagan/ Thompson Plateau, Saxifraga hieraciifolia was found as a rare component of the Sagebrush-Ponderosa Pine/ Montane Spruce ecotone (UAC \# 69944). The site lies just north of the South Thompson river, west of Chase. The McGillvary Mountain fire stopped some $250 \mathrm{~m}$ west of the site in September 2003, so the vegetation is still surviving. The plants were starting to flower on 28 April 2001, amongst Few Flowered Shooting Star (Dodecatheon pulchellum) and Glacier Lily (Erythronium grandiflorum), and scattered individuals of Yellow Bell (Fritillaria pudica) in wet, open areas of the Parkland at an elevation of $445 \mathrm{~m}$. The Hawkweed-Leaved Saxifrage was still flowering in early June, long after the other species were producing seed. This is a vastly different environment to its usual habitat, since it occurs below the Boreal Forest at Chase. The soils are very wet in the Spring due to melting snow. This site also represents a range extension some $8^{\circ} 57^{\prime}$ south of its previously reported most southerly occurrence.

Comparison of these locations with the area glaciated during the Late Wisconsinan event $(25-11 \mathrm{Ka}$
B.P.) shows that the new southern location is unlikely to have been repopulated from the northern populations in unglaciated portions of the Yukon Territory (Figure 1). Since the icesheets covered all the mountains except for the Outer Queen Charlotte Islands (Calder and Taylor 1968) and the easternmost ranges in southwest Alberta (Harris 1997), they would have destroyed all pre-existing vegetation in their path, and repopulation of the area near Chase is most likely to have occurred by migration from a refugium to the south. A third refugium was suggested by Packer and Vitt (1974) at Mountain Park in the front ranges of Central Alberta, but this has been disproved by Strong (1999). In any case, this is too far from Chase to be a likely source.

This implies that the Hawkweed-Leaved Saxifrage must have spread south along the Cordillera to Washington State prior to the Late Wisconsin ice advance. During the latter, all except a small population at the extreme south of its range as well as in Beringia were wiped out. The southern population would have survived where the unglaciated mountains near the ice margin provided a suitable refugium, though it may not have been at a high elevation. Since Parkland vegetation is very widespread today at most elevations, the saxifrage would not have been limited to tundra environments.

When deglaciation occurred, the tops of the mountains emerged first from the ice, but the Early Holocene climate in British Columbia was dry (Alley 1976; Ryder et al. 1991). Thus suitable wet places that would allow it to migrate northwards would have tended to be at lower elevations where the geology permitted springs to be present, while the refugium in which it had survived the glaciation would have tended to become too dry for its continued survival there. This scenario could explain the disjunct areal distribution of the species, and the change in its habitat to the lower parts of the forested areas. 


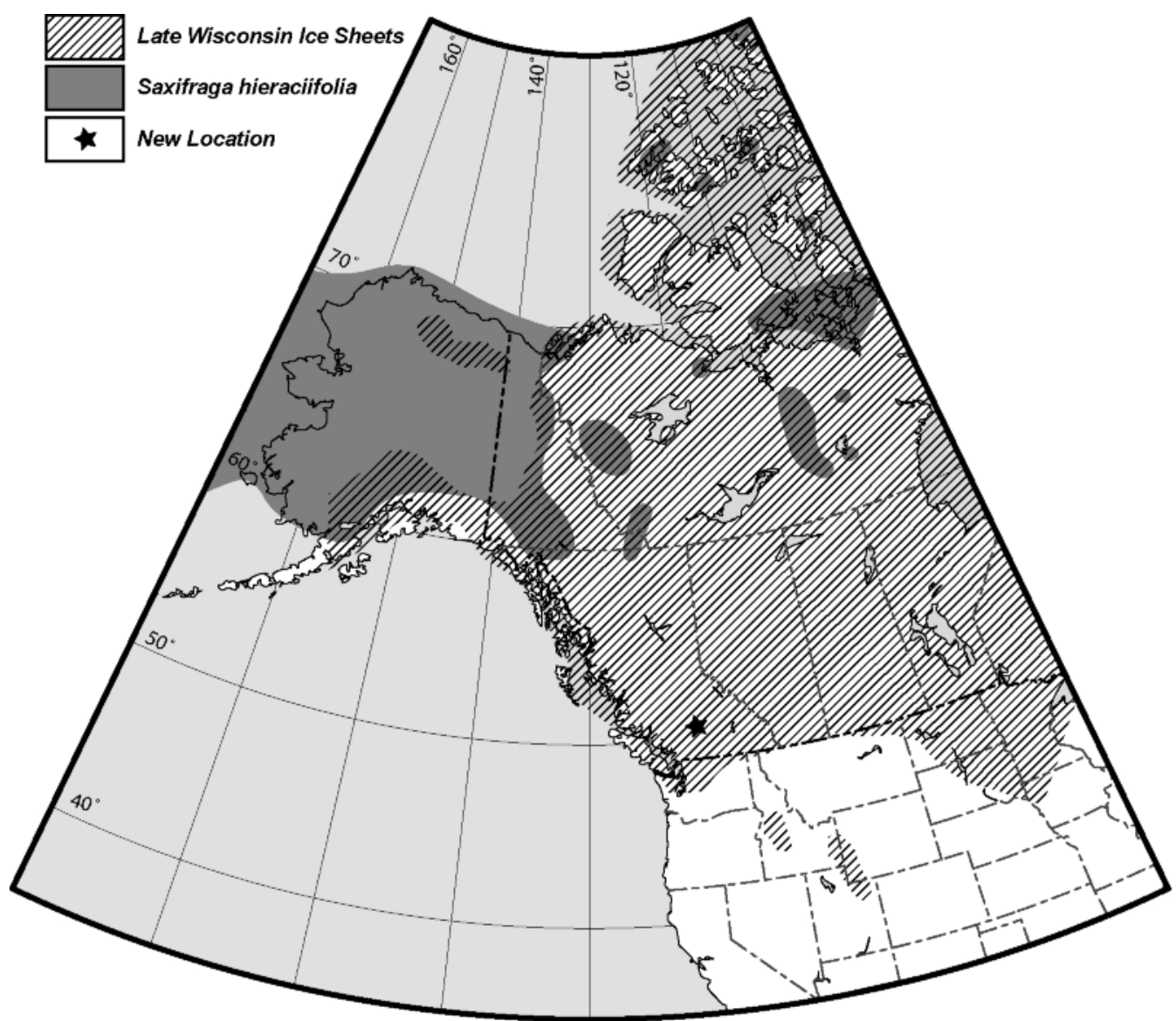

FIGURE 1. Location of the known areas of occurrence of the Hawkweed-Leaved Saxifrage in western Canada in relation to the maximum extent of the Late Wisconsin ice sheets.

In the north, the Hawkweed-Leaved Saxifrage has re-occupied a limited area in northern and southern Yukon, re-colonising it from the population that survived the glaciation in eastern Beringia (i.e., Central Alaska and the western Yukon Territory). In this case, the migration was limited in extent, so that it has only just reached the western margin of the Northwest Territories and northern British Columbia. The isolated pockets to the east in the Northwest Territories presumably survived the ice sheets in local refugia in that region.

\section{Acknowledgements}

Thanks are due W. J. Cody, Agriculture Canada, Ottawa, for information and publications, to an anonymous reviewer for hepful suggestions and to Robin Poitras, cartographer, Department of Geography, University of Calgary, for preparation of the map.

\section{Literature Cited}

Alley, N. F. 1976. The palynology and paleoclimatic significance of a dated core of Holocene peat, Okanagan Valley, southern British Columbia. Canadian Journal of Earth Sciences 13: 1131-1144.

Calder, J. A., and R. L. Taylor. 1968. Flora of the Queen Charlotte Islands, Part I: Systematics of the vascular plants. Research Branch, Department of Agriculture Monograph (4): Part 1. 659 pages.

Cody, W. J. 1996. Flora of the Yukon Territory. National Research Council Press, Ottawa. 643 pages.

Cody, W. J., C. E. Kennedy, and B. Bennett. 1998. New records of vascular plants in the Yukon Territory. Canadian Field-Naturalist 112: 289-328.

Douglas, G. W., D. Meidinger, and J. L. Penny. 2002. Rare vascular plants of British Columbia. $2^{\text {nd }}$ Edition. Crown Publications, Victoria, B.C. 358 pages.

Douglas, G. W., D. Meidinger, and J. Pojar. 2002. Illustrated flora of British Columbia. Volume 8. General Summary, Maps, and Keys. 457 pages. 
Harris, S. A. 1997. Relict Late Quaternary permafrost on a former nunatak at Plateau Mountain, S. W. Alberta, Canada. Biuletyn Peryglacjalny (36): 47-63.

Hultén, E. 1968. Flora of Alaska and neighboring Territories. Stanford University Press, Stanford. 1008 pages.

Packer, J. G., and D. H. Vitt. 1974. Mountain Park: a plant refugium in the Canadian Rocky Mountains. Canadian Journal of Botany 52: 1393-1409.

Porsild, A. E. , and W. J. Cody. 1979. Vascular plants of Continental Northwest Territories, Canada. National Museum of Natural Sciences, Ottawa. 667 pages.

Ryder, J. M., R. J. Fulton, and J. J. Clague. 1991. The Cordilleran Ice Sheet and the glacial geomorphology of southern and central British Columbia. Géomorphologie physique et Quaternaire 45: 365-377.

Straley, G. B., R. L. Taylor and G. W. Douglas. 1985. The rare vascular plants of British Columbia. Syllogeus (59). 165 pages.

Strong, W. L. 1999. Mountain Park area: a plant refugium in the Canadian Rockies? Journal of Biogeography 26: 413-423.

Received 28 June 2001

Accepted 5 November 2003

\title{
A Northern Hawk Owl, Surnia ulula, Nest on a Man-made Structure in Alaska
}

\author{
Michelle L. ReAKofF ${ }^{1}$, JACK L. ReAKOFF ${ }^{1}$ AND Tim CRAiG ${ }^{2}$ \\ ${ }^{1}$ Wiseman, Alaska 99790, USA. \\ ${ }^{2}$ Corresponding author: Northern Field Office, Bureau of Land Management, 1150 University Drive, Fairbanks, Alaska \\ 99708-3844, USA
}

Reakoff, Michelle L., Jack L. Reakoff, and Tim Craig. 2003. A Northern Hawk Owl, Surnia ulula, nest on a man-made structure in Alaska. Canadian Field-Naturalist 117 (2): 306-307.

A Northern Hawk Owl nest was found in a metal cavity on the superstructure of the Trans-Alaska Pipeline. This may be the only record of Northern Hawk Owls nesting on a man-made structure in North America.

Key Words: Northern Hawk Owl, Surnia ulula, nesting, man-made substrate.

Northern Hawk Owls (Surnia ulula) nest at northern latitudes throughout the boreal forests of the world. Little is known about their nesting ecology when compared with other Strigiformes. The nests recorded in North America have all been in natural cavities in cliffs or trees, cavities in trees that have been excavated by other birds, in old stick nests constructed by other birds, or occasionally, on the limbs of conifers (Bent 1938; Terres 1980; Armstrong 1995; Duncan and Duncan 1998). In addition, Northern Hawk Owls sometimes nest among the dense branches of spruce (Picea spp.) that have been parasitized by mistletoe (Arceuthobium campylopodum) in northern Alaska (TC, personal observation). Although Northern Hawk Owls are known to nest in nest boxes in Scandinavia (Sonerud et al. 1987; Voous 1989), we have not found a record of this species nesting on man-made substrates in North America.

On 17 April 2000 Alaska Standard Time MLR visited a study plot close to the Trans-Alaska Pipeline via snow machine to collect data on Snowshoe Hare (Lepus americanus) foraging behavior. While working at the study site, she heard vocalizations in the nearby spruce forest. These calls continued for about
15 minutes, but she did not see the bird responsible for the sounds. Two days later she returned to the study plot and again heard the same vocalizations. When she had finished her work, she walked along the Pipeline and a Northern Hawk Owl flew from a cavity in part of the steel superstructure that supports the Pipeline. Later that day, she investigated the cavity and found a small nest made of twigs, weed stems, grass and owl feathers. Contained within the nest cup were four small white oval eggs. The nest was located $6 \mathrm{~km}$ northeast of Wiseman, Alaska, at $67^{\circ} 27.68^{\prime \prime}$ north latitude and $150^{\circ} 02.66^{\prime \prime}$ west longitude. During these observations snow depth was about $1 \mathrm{~m}$ and the temperature was about $-2^{\circ} \mathrm{C}$.

On 21 April MLR returned to the study plot again, and saw a hawk owl perched in a spruce tree $25 \mathrm{~m}$ from the nest cavity. The owl vocalized repeatedly in her presence, using the same call she had heard before. This vocalization was reminiscent of the "Territorial Call" described by Voous (1989) and the "Advertising Call" described by Duncan and Duncan (1998). When MLR drove a snow machine under the Pipeline support structure, a second owl flew from the cavity. She found six eggs in the nest cup. MLR and JLR visited the 